\title{
Solar drying of residue from Brazil nut processing
}

\author{
Secagem solar do resíduo do processamento da \\ castanha-do-Brasil
}

Ceila Juvino do Nascimento ${ }^{1}$, Maria Helena da Silva Oliveira ${ }^{1}$, Dyego da Costa Santos ${ }^{1 *} \mathbb{D}$,
Thalis Leandro Bezerra de Lima ${ }^{2}$, Daniela Dantas de Farias Leite ${ }^{2}$, João Paulo de Lima Ferreira ${ }^{2}$,
Rossana Maria Feitosa de Figueirêdo ${ }^{2}$, João Paulo Castelo Feitosa', Emerson Zambrano Lara'

${ }^{1}$ Instituto Federal de Educação, Ciência e Tecnologia do Acre (IFAC), Departamento de Tecnologia em Agroindústria, Xapuri/AC - Brasil

2Universidade Federal de Campina Grande (UFCG), Unidade Acadêmica de Engenharia Agrícola, Campina

Grande/PB - Brasil

${ }^{*}$ Corresponding Author: Dyego da Costa Santos, Instituto Federal de Educação, Ciência e Tecnologia do Acre (IFAC), Departamento de Tecnologia em Agroindústria, Rua Coronel Brandão, 1622, Centro, CEP: 69930-000,

Xapuri/AC - Brasil, e-mail: dyego.csantos@gmail.com

Cite as: Nascimento, C. J., Oliveira, M. H. S., Santos, D. C., Lima, T. L. B., Leite, D. D. F., Ferreira, J. P. L., Figueirêdo, R. M. F., Feitosa, J. P. C., \& Lara, E. Z. (2021). Solar drying of residue from Brazil nut processing. Brazilian Journal of Food Technology, 24, e2020297. https://doi.org/10.1590/1981-6723.29720

\begin{abstract}
Brazil nuts are often used for direct consumption or in the preparation process of water-soluble extract. After obtaining the water-soluble extract, a large amount of Brazil nut residues with good sensory characteristics are generated. Thus, this study aimed to dry Brazil nut processing residues in layers with different thicknesses in a direct solar dryer as well as by direct exposure to the sun, in order to fit different mathematical models to the experimental data of drying kinetics, and calculate the drying rates and effective diffusivity. The drying procedures began at 9 a.m. on a concrete base, for samples dried by direct exposure to the sun, and in a solar dryer constructed with expanded polystyrene foam zinc plated and a glass cover. The mass loss of the samples was monitored by weighing at regular times until the hygroscopic equilibrium was obtained. The direct solar dryer had temperatures about $80 \%$ higher than those recorded in the open environmental air temperature. Drying rates were higher in dehydrations performed in the solar dryer compared to the drying by exposure to the sun. The Midilli model was selected as the most adequate for predicting the drying of the samples under all experimental conditions, showing coefficients of determination above 0.99 . The effective diffusion coefficients of moisture were higher in samples dehydrated in the solar dryer when compared to those dried by exposure to the sun. Regarding the research conducted under the experimental conditions of this study, the performance of the solar dryer to dry Brazil nut processing residues was satisfactory.
\end{abstract}

Keywords: Bertholletia excelsa H.B.K.; Agro-industrial residues; Solar dryer; Drying rate; Mathematical modeling; Effective diffusivity.

\section{Resumo}

A castanha-do-Brasil é frequentemente utilizada para consumo direto ou utilizada no processamento de extrato hidrossolúvel. Após obtenção do extrato hidrossolúvel, é gerada uma grande quantidade de farinha de castanha- 
do-Brasil com boas características sensoriais. Assim, objetivou-se secar a farinha de castanha-do-Brasil com diferentes espessuras de camada em secador solar de uso direto e por exposição direta ao sol, além de ajustar diferentes modelos matemáticos aos dados experimentais de cinética de secagem e calcular as taxas de secagem e a difusividade efetiva. As secagens foram iniciadas às $9 \mathrm{~h}$ da manhã, em base de concreto, para as amostras secadas por exposição ao sol, e em secador solar, construído com chapa de zinco revestido de poliestireno expandido e possuindo um vidro como cobertura. A perda de massa das amostras foi monitorada através de pesagens em tempos regulares até obter equilíbrio higroscópico. O secador solar de uso direto apresentou temperaturas cerca de $80 \%$ superiores em comparação às temperaturas registradas no ambiente. As taxas de secagem foram maiores nas desidratações realizadas no secador solar em comparação à secagem por exposição ao sol. O modelo de Midilli foi selecionando como o mais adequado para predição da secagem das amostras em todas as condições experimentais, apresentando coeficientes de determinação superiores a 0,99. Os coeficientes de difusão efetivos de umidade foram maiores nas amostras desidratadas no secador solar em comparação à secagem por exposição ao sol. Nas condições experimentais deste estudo, o desempenho do secador solar para secagem de farinha residual de castanha-do-Brasil mostrou-se satisfatório.

Palavras-chave: Bertholletia excelsa H.B.K.; Resíduo agroindustrial; Secador solar; Taxa de secagem; Modelagem matemática; Difusividade efetiva.

\section{Introduction}

The endosperm of Brazil nuts can be consumed fresh, dehydrated, salted or in many forms. It can also be used in the form of flour or water-soluble extract (Ferberg et al., 2002). The water-soluble extract, popularly known as Brazil nut 'milk', has been included in the diet of individuals who have allergies and/or intolerance to animal milk, or used by those who wish to develop healthier eating habits.

The production process basically consists in disintegrating the endosperm in drinking water, followed by filtration, heat treatment and packaging, to obtain a protein-rich water-soluble extract with high market potential (Kluczkovski et al., 2017). The production of Brazil nut 'milk' generates a residue with high nutritional value, consisting of the crushed endosperm. This by-product can be incorporated into dairy products, bakery products, chocolates, among others (Gomes \& Torres, 2016). As this residue has high moisture content, its useful life is limited and the adoption of cold as an important mean of conservation is too expensive due to the high energy consumption, then, it is necessary to adopt an economically viable conservation technology, such as dehydration, which aims to reduce excess moisture.

For the dehydration of Brazil nut residues, it is possible to use the solar method, both by direct exposure to the sun and by solar dryers. Drying by direct exposure to the sun is a simple and low-cost alternative to dehydrate agricultural products (Santos et al., 2015). However, the relatively low ambient temperatures require more time to reduce moisture to safe levels and, additionally, there is the risk of contamination of the product by insects (Singh et al., 2020). Thus, to overcome these disadvantages, drying in solar dryers is a promising alternative to replace drying by exposure to the sun (Seerangurayar et al., 2019), as the dryers are developed to save time and maintain the quality of the products (Tagnamas et al., 2019).

According to Kesavan et al. (2019), solar dryers are generally classified as direct or indirect, based on the arrangement of their components and on their use. Direct dryers consist of a drying chamber covered by a transparent cover made of glass or plastic and have holes to enable air circulation. In this type of dryer, moisture is removed by the direct incidence of solar radiation on the product, regardless of whether or not there is natural ventilation (Guiné \& Barroca, 2017). In indirect dryers, atmospheric air is heated in solar collectors and flows in the drying chamber where the products are stored. Studies on the solar drying of agricultural residues include jackfruit seeds (Queiroz et al., 2011), annatto grains (Santos et al., 2015), grape bagasse (Aktaş et al., 2019), tomato bagasse (Badaoui et al., 2019), among others. However, no study was found in the literature about the drying of residues from the extraction of Brazil nut water-soluble extract. Thus, this study aimed to dry the residue 
from Brazil nut processing in layers with different thicknesses in a direct solar dryer and by direct exposure to the sun, in order to fit different mathematical models to the experimental data of drying kinetics, and calculate the drying rates and effective diffusivity of each experiment.

\section{Material and methods}

\subsection{Material}

It was used Brazil nuts (Bertholletia excelsa H.B.K.), 2019 season, from the Agroforestry Center of the city of Xapuri, AC, Brazil. The seed coats were manually removed using a stainless steel knife to obtain the endosperm, which were washed in running water, after pellicle removal, and sanitized in chlorinated solution (100 ppm of active chlorine) for $15 \mathrm{~min}$. Subsequently, the endosperm was used to obtain the water-soluble extract of Brazil nuts, through its disintegration in distilled water at the proportion of $1: 2 \mathrm{~m} / \mathrm{m}$ (endosperm:water), in an industrial blender for $5 \mathrm{~min}$, followed by filtration through a sieve with cotton, which enabled the separation between residue and water-soluble extract. The Brazil nut residue was placed in low-density polyethylene packages and stored in a horizontal freezer at $-18{ }^{\circ} \mathrm{C}$, until the experiments were carried out.

\subsection{Solar dryer}

A solar dryer was built with rectangular zinc plate, measuring $30 \mathrm{~cm}$ wide, $50 \mathrm{~cm}$ long and $18 \mathrm{~cm}$ deep. The solar dryer was internally lined with dark-colored expanded polystyrene and covered with a $4 \mathrm{~mm}$-thick, flat, transparent glass. The sides of the dryer had openings with $1.4 \mathrm{~cm}$ diameter for exhausting the moisture to be lost by the samples. The interior of the dryer also had a flat zinc plate $(46.5 \times 26.5 \mathrm{~cm})$ positioned on the expanded polystyrene and painted black.

\subsection{Sample preparation}

Regarding the drying experiments, the Brazilian nut residue was previously defrosted under refrigeration $\left(4{ }^{\circ} \mathrm{C}\right)$ and kept on a laboratory bench for equalization between ambient and sample temperatures. Subsequently, about 20, 40 and $60 \mathrm{~g}$ of residues were spread on aluminum trays with layer thicknesses of approximately $11.95,8.06$ and $4.11 \mathrm{~mm}$, respectively, and subjected to solar drying, in triplicate, both in the solar dryer and by direct exposure to the sun on an elevated concrete base, where the samples were arranged on trays and exposed to the sun (control sample). A cardboard windshield was used to protect the samples while conducting the experiments of drying by exposure to the sun. The initial moisture content of the samples was determined in an oven at $105^{\circ} \mathrm{C} / 24 \mathrm{~h}$ (Instituto Adolfo Lutz, 2008).

\subsection{Drying process}

The drying procedures began at approximately 9 a.m., and mass loss in the samples was monitored by weighing at regular intervals of 5, 10, 15, 30 and $60 \mathrm{~min}$. When the residues in the solar dryer reached hygroscopic equilibrium with the environment, i.e., when no more mass variation was recorded, the drying processes in solar dryer and by exposure to the sun ended and the moisture content was determined (Instituto Adolfo Lutz, 2008). The products obtained from the drying were flours from Brazil nut processing residue. During the drying, a mercury thermometer was used to monitor the temperatures inside the dryer and in the environment. Data of relative humidity in the environment and solar radiation were obtained from the National Institute of Meteorology (Instituto Nacional de Meteorologia, 2019). From the equilibrium moisture contents, final moisture contents and moisture contents at each drying time interval, the curves of moisture content ratio as a function of drying time were calculated according to Equation 1. 
$R X=\frac{X-X_{e}}{X_{i}-X_{e}}$

where RX - moisture content ratio (dimensionless); X - moisture content, d.b.; $\mathrm{X}_{\mathrm{i}}$ - initial moisture content, d.b.; $\mathrm{X}_{\mathrm{e}}$ - equilibrium moisture content, d.b.

\subsection{Data modeling}

The mathematical models described in Table 1 were fitted to the curves of the moisture content ratio of the solar drying of Brazil nut residue flour, using the Statistica 7.0 software, through nonlinear regression by the Quasi-Newton method.

Table 1. Mathematical models fitted to the curves of drying kinetics of Brazil nut residue with different thicknesses in solar dryer and by direct exposure to the sun.

\begin{tabular}{ccc}
\hline Designation & Mathematical models \\
\hline Henderson e Pabis & $\mathrm{RX}=\mathrm{a} \exp (-\mathrm{k} \mathrm{t})$ \\
\hline Midilli & $\mathrm{RX}=\mathrm{a} \exp \left(-\mathrm{k} \mathrm{t}^{\mathrm{n}}\right)+\mathrm{bt}$ \\
\hline Newton & $\mathrm{RX}=\exp (-\mathrm{kt})$ & $(3)$ \\
\hline Page & $\mathrm{RX}=\exp \left(-\mathrm{k} \mathrm{t} \mathrm{n}^{\mathrm{n}}\right)$ \\
\hline Silva & $\mathrm{RX}=\exp \left(\mathrm{at}-\mathrm{b} \mathrm{t} \mathrm{t}^{0,5}\right)$ \\
\hline
\end{tabular}

$\mathrm{RX}=$ moisture ratio of the sample, dimensionless; $\mathrm{k}=$ drying constant; $\mathrm{a}, \mathrm{b}, \mathrm{c}, \mathrm{n}=$ coefficients of the models; $\mathrm{t}=$ drying time (min).

The criteria for fitting the mathematical models to the experimental data of the drying kinetics were related to the magnitudes of the coefficient of determination $\left(\mathrm{R}^{2}\right)$, chi-square $\left(\chi^{2}\right)$ and the Mean Square Deviation (MSD), respectively according to Equations 2, 3 and 4.

$$
\begin{aligned}
& \mathrm{R}^{2}=1-\left(\frac{\sum_{\mathrm{i}=1}^{\mathrm{n}}\left(\mathrm{RX}_{\text {pred }, \mathrm{i}}-\mathrm{RX}_{\text {exp }, \mathrm{i}}\right)^{2}}{\sum_{\mathrm{i}=1}^{\mathrm{n}}\left(\mathrm{RX}_{\text {exp }, \mathrm{i}}-\mathrm{RX}_{\text {pred }, \mathrm{i}}\right)^{2}}\right) \\
& \chi^{2}=\frac{1}{\mathrm{n}-\mathrm{N}} \sum_{\mathrm{i}=1}^{\mathrm{n}}\left(\mathrm{RX}_{\text {exp }, \mathrm{i}}-\mathrm{RX}_{\text {pred }, \mathrm{i}}\right)^{2} \\
& \mathrm{MSD}=\left[\frac{1}{\mathrm{n}} \sum_{\mathrm{i}=1}^{\mathrm{n}}\left(\mathrm{RX}_{\text {pred }, \mathrm{i}}-\mathrm{RX}_{\text {exp }, \mathrm{i}}\right)^{2}\right]^{\frac{1}{2}}
\end{aligned}
$$

where $\mathrm{R}^{2}$ - coefficient of determination; $\chi^{2}$ - chi-square; MSD; $\mathrm{RX}_{\text {pred, }}$ - moisture content ratio predicted by the model; $\mathrm{RX}_{\text {exp, } \mathrm{i}}$ - experimental moisture content ratio; $\mathrm{n}$ - number of observations; $\mathrm{N}$ - number of constants of the model.

\subsection{Drying rate}

The Brazil nut residue drying rates were calculated from the moisture contents (d.b.) at each drying time interval according to Equation 5.

$\mathrm{TX}=\frac{\mathrm{X}_{\mathrm{t}-\mathrm{X}_{\mathrm{t}+\Delta \mathrm{t}}}}{\Delta \mathrm{t}}$

where TX - drying rate, $\mathrm{kg}$ of water $\mathrm{kg}$ of dry matter $\min ^{-1} ; \mathrm{X}_{\mathrm{t}+\Delta \mathrm{t}}$ - moisture content at $\mathrm{t}+\Delta \mathrm{t}$, d.b.; $\mathrm{X}_{\mathrm{t}}$ - moisture content at a specific time, d.b.; $\Delta \mathrm{t}$ - time interval between two consecutive measurements; $\mathrm{t}$ - time, min. 


\subsection{Moisture effective diffusivity}

The mathematical model of liquid diffusion with five-term approximation (Equation 6), considering the geometric shape of the Brazil nut residue in different thicknesses $(11.95,8.06$ and $4.11 \mathrm{~mm})$ as similar to that of an infinite flat plate, was fitted to the curves of drying in solar dryer and by direct exposure to the sun. Uniform distribution of the initial moisture content and absence of thermal resistance were adopted in the calculation of moisture effective diffusivity.

$$
R X=\frac{X-X_{e}}{X_{I}-X_{e}}=\frac{8}{\pi^{2}} \sum_{n=0}^{\infty} \frac{1}{(2 n+1)^{2}} \exp \left[-(2 n+1)^{2} \pi^{2} D_{\text {eff }} \frac{t}{4 L^{2}}\right]
$$

where $D_{\text {eff }}$ - effective diffusion coefficient, $\mathrm{m}^{2} \mathrm{~s}^{-1} ; \mathrm{n}$ - number of terms of the equation; $\mathrm{L}$ - characteristic dimension (half thickness of the layer), $m$; $t$ - time, $s$.

\section{Results and discussion}

\subsection{Environmental conditions}

Figure 1 shows the temperature variation inside the solar dryer and in the external environment during the drying of Brazil nut residue in layers with different thicknesses. It was observed that the average ambient temperatures were $39.73,38.86$ and $41.67{ }^{\circ} \mathrm{C}$, for the respective thicknesses of $11.95,8.06$ and $4.11 \mathrm{~mm}$, while average temperatures of $71.92,71.52$ and $74.87{ }^{\circ} \mathrm{C}$ were recorded inside the solar dryer for the thicknesses of $11.95,8.06$ and $4.11 \mathrm{~mm}$, respectively. At the moment of the ambient temperature measurements, the thermometer was positioned close to where the samples were located, fixed in the windshield. Thus, the relatively high ambient temperatures are probably due to heat exchanges between the concrete base and the aluminum trays, which are good thermal conductors.
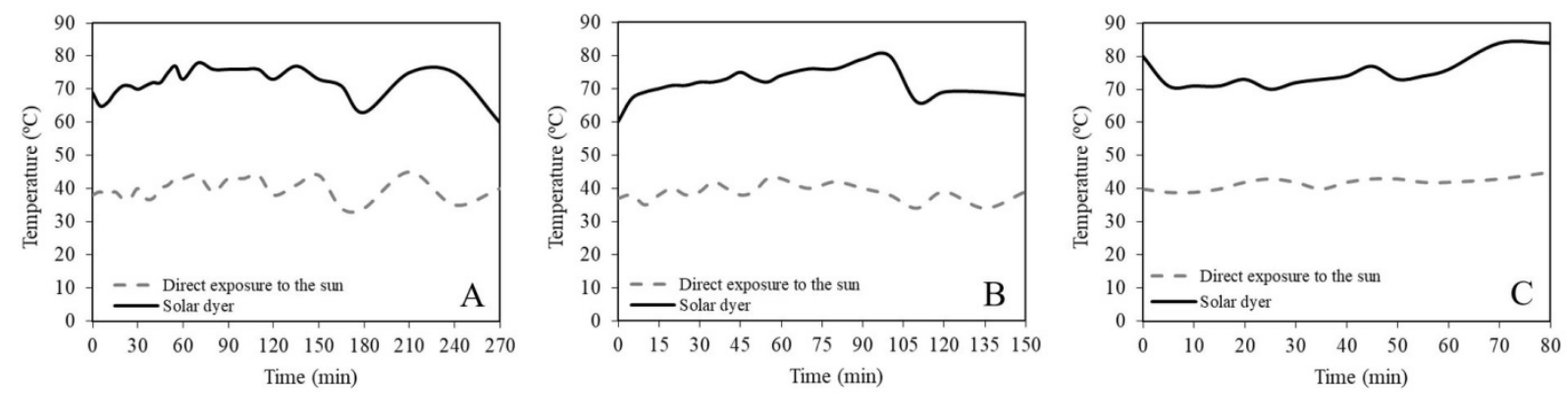

Figure 1. Temperature variation inside the solar dryer and in the external environment during the drying of Brazil nut residue with thicknesses of $11.95 \mathrm{~mm}(\mathrm{~A}), 8.06 \mathrm{~mm}(\mathrm{~B})$ and $4.11 \mathrm{~mm}(\mathrm{C})$ in solar dryer and by direct exposure to the sun.

In all experiments, the temperature inside the solar dryer was about $80 \%$ higher compared to the ambient temperature, hence constituting an important parameter to characterize the performance of the device, since the high temperature recorded in the solar dryer favors the drying due to the increase in the evaporation capacity of the dehydration air (Hamdi et al., 2019). This behavior is often reported in direct solar dryers (Santos et al., 2014a; Patil \& Gawande, 2018; Hempattarasuwan et al., 2020), since in this type of dryer both the drying air and the sample are heated by the greenhouse effect (Vidaña et al., 2019). During the experiments, temperature fluctuations were observed both in the drying by direct exposure to the sun and in the solar dryer, related to the presence of some clouds, which may affect the incidence of solar radiation according to Hamdi et al. (2019).

The data of Relative Humidity (RH) and solar radiation of the external environment during the drying of Brazil nut residue with different thicknesses in the solar dryer and by direct exposure to the sun are shown in 
Figure 2. The average values of RH were $53.80,62.50 \%$ and $61.67 \%$ for the drying of samples with thicknesses of $11.95,8.06$ and $4.11 \mathrm{~mm}$, respectively, while the average values of solar radiation were $2,397.60,2,319.50$ and $2,070.00 \mathrm{~kJ} \mathrm{~m}^{2}$ for the respective thicknesses of $11.95,8.06$ and $4.11 \mathrm{~mm}$. It was noted that the increase in solar radiation values along the drying contributed to the reduction of ambient $\mathrm{RH}$ in all experiments, which according to Murali et al. (2019) could favor the conditions of drying by exposure to the sun. This behavior was also observed by Santos et al. (2015) in the solar drying of residual grains of annatto. Nevertheless, it was observed that all drying processes were conducted within an ambient RH range of $43 \%$ to $72 \%$, which is relatively high, but close to the range reported by Kesavan et al. (2019) for the solar drying of potato slices, from $58 \%$ to $76 \%$.

Although the RH was not monitored inside the solar dryer during the drying of Brazil nuts, it can be inferred that the RH inside this device was lower than the RH of the external environment due to the higher temperatures recorded (Figure 1), which enhanced the drying of the samples in the solar dryer. It is known that under low RH there is higher capacity for moisture diffusion from the sample to the drying air, so there was significant improvement in the drying capacity of the air. This is in agreement with the results of Lingayat et al. (2017), who investigated the solar drying of bananas and found that the solar dryer temperature was higher than the temperature recorded in the environment, which contributed to obtain lower RH inside the device. Hempattarasuwan et al. (2020) found RH inside the solar dryer about 20 to $40 \%$ lower compared to that of the environment, owing to the higher temperatures observed in the solar dryer.
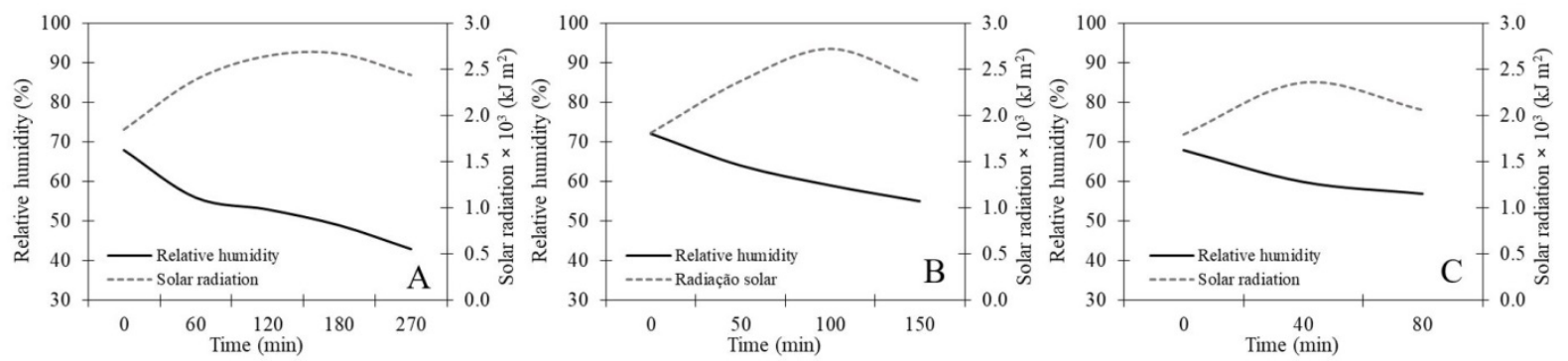

Figure 2. Variation of Relative Humidity $(\mathrm{RH})$ and solar radiation in the external environment during the drying of Brazil nut residue with thicknesses of $11.95 \mathrm{~mm}(\mathrm{~A}), 8.06 \mathrm{~mm}(\mathrm{~B})$ and $4.11 \mathrm{~mm}(\mathrm{C})$ in solar dryer and by direct exposure to the sun. Source: Instituto Nacional de Meteorologia (2019).

\subsection{Equilibrium moisture content}

Figure 3 shows the variation in moisture content during drying by direct exposure to the sun and in solar dryer of Brazil nut flour with different thicknesses. In all experiments, the drying curves showed an exponential behavior, also verified by Vidaña et al. (2019) in the solar drying of blackberry. Drying occurred more quickly at the beginning of the process compared to the final minutes, a period in which the moisture curves showed a sharper inclination, a behavior also reported by Lakshmi et al. (2019) when studying the solar drying of Curcuma zedoaria (Christm.) Roscoe. This is related to the greater availability of free water on the sample surface at the beginning of the process, which is quickly evaporated. The times required for the samples of the solar dryer to reach the hygroscopic equilibrium were 270, 150 and $80 \mathrm{~min}$ for the thicknesses of 11.95, 8.06 and $4.11 \mathrm{~mm}$, respectively. It was observed that the sample with the lowest layer thickness also had the shortest drying time, about $70.37 \%$ lower, possibly due to the greater contact of the product with the drying air. According to Doymaz (2017), thinner samples could dry faster due to the reduction in the distance traveled by moisture and to the increase in the surface area exposed to a given volume of the product. In other words, the resistance to moisture movement is lower in thinner samples (Hussein et al., 2016). Reyes et al. (2019) dehydrated kiwi with thicknesses of 4 and $8 \mathrm{~mm}$ in solar dryer and found the shortest drying time for the smallest thickness. 

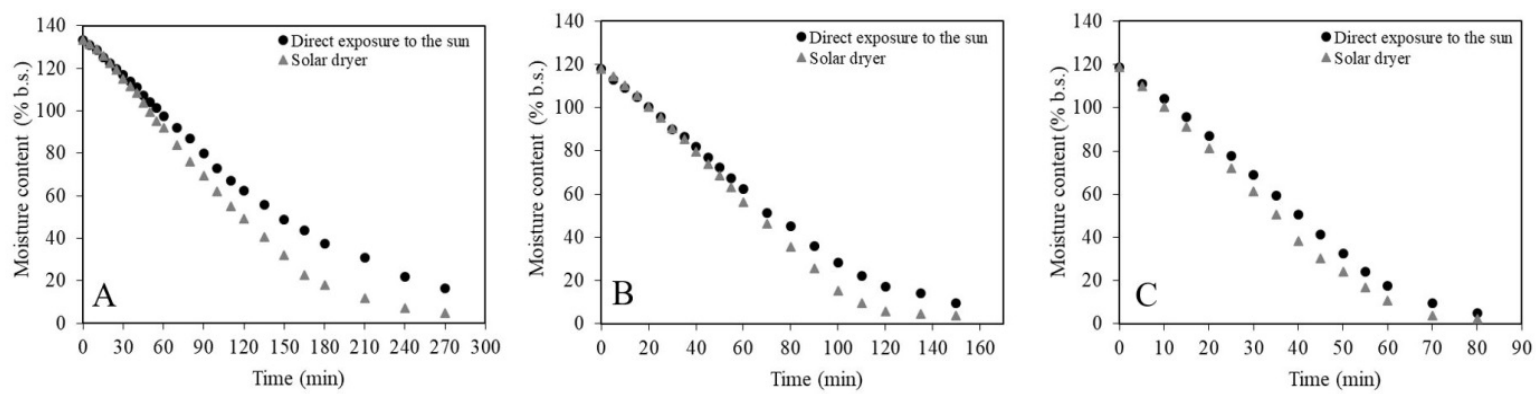

Figure 3. Evolution of moisture (\% d.b.) during the drying of Brazil nut residue with thicknesses of $11.95 \mathrm{~mm}(\mathrm{~A})$, $8.06 \mathrm{~mm}(\mathrm{~B})$ and $4.11 \mathrm{~mm}(\mathrm{C})$ in a solar dryer and by direct exposure to the sun.

The average initial moisture content of Brazil nut residue was 123.34\% d.b., which was reduced to 4.91, 3.60 and $2.15 \%$ d.b. for the respective thicknesses of $11.95,8.06$ and $4.11 \mathrm{~mm}$, when the samples were dried in the solar dryer. On the other hand, the samples dried by exposure to the sun showed final moisture contents of $16.50,9.32$ and $4.97 \%$ d.b. for the thicknesses of $11.95,8.06$ and $4.11 \mathrm{~mm}$, respectively. These values are below the minimum of $25 \%$ moisture content specified by legislation (Brasil, 2005) for dehydrated fruit products. Considering the thicknesses individually, lower moisture contents were obtained in the samples of the solar dryer, possibly related to the higher temperatures recorded in this device, which increase the moisture removal rate and make the drying curves steeper (Lingayat et al., 2020). Alara et al. (2019) reported that at higher temperatures, the heat transfer between the drying air and the sample is intensified, causing greater moisture removal. It was also observed that the differences between the drying processes in solar dryer and by exposure to the sun were high, corresponding to 336.05, 258.89 and $231.16 \%$ for the respective thicknesses of $11.95,8.06$ and $4.11 \mathrm{~mm}$. However, in the smallest layer thickness the difference between the final moisture contents of samples dried in the solar dryer and by direct exposure to the sun was about $104.89 \%$ lower, suggesting that the use of the solar dryer is more efficient in layers with greater thicknesses.

\subsection{Drying rates}

The drying rates of Brazil nut residues in different thicknesses dehydrated in a solar dryer and by direct exposure to the sun are presented in Figure 4. All experiments occurred in a falling rate period, and no period with constant drying rate was detected. This indicates that moisture migration occurred through the mechanism of diffusion (Santos et al., 2019), involving water in the liquid and vapor states, a phenomenon that depends on temperature and on the characteristics of the sample (Patil \& Gawande, 2018; Mghazli et al., 2017). This behavior was also reported by Santos et al. (2013) in the drying of residual grains of annatto. The maximum drying rates recorded in the solar dryer were $0.86,1.39$ and $2.43 \mathrm{~kg}$ of water $\mathrm{kg}$ of dry matter $\mathrm{min}^{-1}$ for the thicknesses of $11.95,8.06$ and $4.11 \mathrm{~mm}$, respectively, while samples dehydrated by direct exposure to the sun had maximum drying rates of $0.73,1.19$ and $1.87 \mathrm{~kg}$ of water kg of dry matter $\mathrm{min}^{-1}$ for the respective thicknesses of $11.95,8.06$ and $4.11 \mathrm{~mm}$. The high drying rates at the beginning of the process were due to the removal of surface moisture from the residues by the drying air (Murali et al., 2019), enhanced by the granular characteristic of the samples, which were previously disintegrated, which possibly facilitated the diffusion of water vapor through intergranular spaces.
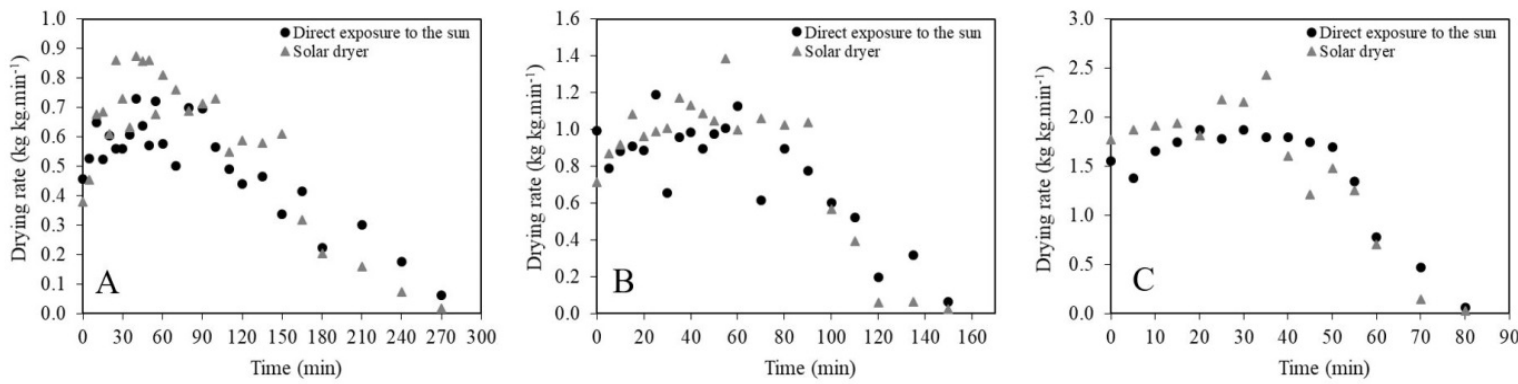

Figure 4. Average drying rates of Brazil nut residue with thicknesses of $11.95 \mathrm{~mm}(\mathrm{~A}), 8.06 \mathrm{~mm}(\mathrm{~B})$ and $4.11 \mathrm{~mm}$ (C) in solar dryer and by direct exposure to the sun. 
By comparing the magnitudes of the drying rates at the beginning of the dehydrations in solar dryer and by exposure to the sun, it was observed that the use of the solar dryer made it possible to obtain the highest values, which are related to the higher temperatures recorded in this device (Lakshmi et al., 2019), enabling a greater moisture gradient between the sample and the drying air. The drying rates of samples dried in the solar dryer were about $17.81 \%, 16.81 \%$ and $29.95 \%$ higher than those of the residues dehydrated by exposure to the sun, for the respective thicknesses of $11.95,4.06$ and $8.11 \mathrm{~mm}$. These results were similar to those of Hamdi et al. (2019), who dried red pepper slices in solar dryer and by direct exposure to the sun and observed an approximately $20 \%$ higher drying rate in the sample of the solar dryer.

It was found that the drying rate was significantly reduced with the decrease of moisture content, since the remaining water was located in the innermost regions of the samples. This led to a higher energy demand in the final stages of the process (Santos et al., 2013), justifying the reduction in the rate of water removal per unit of time (Lakshmi et al., 2019). Singh et al. (2020) dehydrated several plant materials (Phyllanthus emblica (L.) and Aegle marmelos (L.) fruits and Aloe vera (L.) Burm. f) by direct exposure to the sun and in solar dryer and found similar behavior, with reduction in the drying rate throughout the dehydrations. As the layer thickness decreased, the contact surface of the product with the drying air increased, which enabled greater transfer of moisture as the dehydration progressed and the obtaining of higher drying rates in samples with lower thicknesses, a phenomenon also observed by Doymaz (2017) in carrot slices with thicknesses of 4, 7 and $10 \mathrm{~mm}$.

\subsection{Mathematical modeling of the drying process}

The moisture content data of the samples as a function of time were converted to moisture ratio, from Equation 1, in order to standardize the curves of drying kinetics. The fitting parameters of the mathematical models to the moisture ratio curves of Brazil nut residue with different thicknesses, dried in solar dryer and by direct exposure to the sun, are shown in Table 2 .

Table 2. Parameters, coefficients of determination $\left(\mathrm{R}^{2}\right)$, Mean Square Deviations (MSD) and chi-squares $\left(\chi^{2}\right)$ of the mathematical models fitted to the experimental data of drying of Brazil nut residue with different thicknesses in solar dryer and by direct exposure to the sun.

\begin{tabular}{|c|c|c|c|c|c|c|}
\hline Models & $\mathbf{L}(\mathbf{m m})$ & Drying type & Parameters of models & $\mathbf{R}^{2}$ & MSD & $\chi^{2}\left(\times 10^{-4}\right)$ \\
\hline \multirow{6}{*}{$\begin{array}{l}\text { Henderson e } \\
\text { Pabis }\end{array}$} & 11.95 & SD & a: $1.1066 ; \mathrm{k}: 0.0096$ & 0.9699 & 0.0570 & 35.1423 \\
\hline & 11.95 & ES & a: $1.0805 ; \mathrm{k}: 0.0084$ & 0.9759 & 0.0474 & 24.3590 \\
\hline & 8.06 & SD & a: $1.1270 ; \mathrm{k}: 0.0165$ & 0.9427 & 0.0813 & 73.0059 \\
\hline & 8.06 & ES & a: $1.0968 ; \mathrm{k}: 0.0151$ & 0.9580 & 0.0650 & 46.6471 \\
\hline & 4.11 & SD & a: $1.1071 ; \mathrm{k}: 0.0311$ & 0.9512 & 0.0728 & 61.1875 \\
\hline & 4.11 & ES & a: $1.1102 ; \mathrm{k}: 0.0276$ & 0.9437 & 0.0766 & 67.6624 \\
\hline \multirow{6}{*}{ Midilli } & 11.95 & SD & a: $0.9907 ;$ b: $-0.000168 ; \mathrm{k}: 0.0008 ; \mathrm{n}: 1.4901$ & 0.9993 & 0.0085 & 0.8498 \\
\hline & 11.95 & ES & a: $0.9925 ; \mathrm{b}:-0.000333 ; \mathrm{k}: 0.0015 ; \mathrm{n}: 1.3190$ & 0.9997 & 0.0055 & 0.3567 \\
\hline & 8.06 & SD & a: $0.9699 ;$ b: $-0.000398 ; \mathrm{k}: 0.0006 ; \mathrm{n}: 1.7399$ & 0.9972 & 0.0180 & 4.0140 \\
\hline & 8.06 & ES & a: $0.9755 ;$ b: $-0.000644 ; \mathrm{k}: 0.0015 ; \mathrm{n}: 1.4729$ & 0.9986 & 0.0120 & 1.7683 \\
\hline & 4.11 & SD & a: $0.9762 ;$ b: $-0.000858 ; \mathrm{k}: 0.0029 ; \mathrm{n}: 1.5910$ & 0.9979 & 0.0150 & 3.0629 \\
\hline & 4.11 & ES & a: $0.9804 ;$ b: $-0.001359 ; \mathrm{k}: 0.0023 ;$ n: 1.5817 & 0.9984 & 0.0092 & 2.3164 \\
\hline \multirow{6}{*}{ Newton } & 11.95 & SD & $\mathrm{k}: 0.0084$ & 0.9491 & 0.0740 & 56.6432 \\
\hline & 11.95 & ES & k: 0.0075 & 0.9615 & 0.0600 & 37.4467 \\
\hline & 8.06 & SD & k: 0.0143 & 0.9192 & 0.0965 & 97.8341 \\
\hline & 8.06 & ES & $\mathrm{k}: 0.0134$ & 0.9418 & 0.0764 & 61.3310 \\
\hline & 4.11 & SD & $\mathrm{k}: 0.0280$ & 0.9355 & 0.0837 & 75.0931 \\
\hline & 4.11 & ES & $\mathrm{k}: 0.0246$ & 0.9252 & 0.0624 & 83.4104 \\
\hline \multirow{2}{*}{ Page } & 11.95 & SD & k: $0.0008 ; \mathrm{n}: 1.5082$ & 0.9982 & 0.0141 & 2.1567 \\
\hline & 11.95 & ES & k: $0.0012 ; \mathrm{n}: 1.3989$ & 0.9973 & 0.0158 & 2.7142 \\
\hline
\end{tabular}


Table 2. Continued.

\begin{tabular}{|c|c|c|c|c|c|c|}
\hline Models & $\mathbf{L}(\mathbf{m m})$ & Drying type & Parameters of models & $\mathbf{R}^{2}$ & MSD & $\chi^{2}\left(\times 10^{-4}\right)$ \\
\hline & 8.06 & SD & k: $0.0008 ; n: 1.6965$ & 0.9933 & 0.0277 & 8.4983 \\
\hline & 8.06 & ES & $\mathrm{k}: 0.0015 ; \mathrm{n}: 1.5253$ & 0.9941 & 0.0244 & 6.5953 \\
\hline & 4.11 & SD & k: $0.0028 ; n: 1.6393$ & 0.9944 & 0.0247 & 7.0400 \\
\hline & 4.11 & ES & k: $0.0020 ; \mathrm{n}: 1.6862$ & 0.9933 & 0.0187 & 8.0396 \\
\hline \multirow{6}{*}{ Silva } & 11.95 & SD & a: $0.0136 ;$ b: -0.0486 & 0.9871 & 0.0372 & 15.0202 \\
\hline & 11.95 & ES & a: $0.0113 ; b:-0.0360$ & 0.9885 & 0.0327 & 11.6028 \\
\hline & 8.06 & SD & a: $0.0249 ;$ b: -0.0795 & 0.9696 & 0.0592 & 38.7104 \\
\hline & 8.06 & ES & a: $0.0213 ;$ b: -0.0605 & 0.9773 & 0.0477 & 25.1978 \\
\hline & 4.11 & SD & a: $0.0465 ; b:-0.1073$ & 0.9766 & 0.0505 & 29.3884 \\
\hline & 4.11 & ES & a: $0.0417 ;$ b: -0.1026 & 0.9718 & 0.0383 & 33.8440 \\
\hline
\end{tabular}

$\mathrm{L}=$ Thickness; $\mathrm{SD}=$ Solar Dryer; $\mathrm{ES}=$ Direct Exposure to the Sun.

All mathematical models evaluated showed $\mathrm{R}^{2}$ values higher than 0.90 , and only the Midilli, Page and Silva models had all the magnitudes of $\mathrm{R}^{2}$ higher than 0.95, which according to Madamba et al. (1996) allowed these models to be classified as acceptable to describe the drying process. However, for selecting the best mathematical model, the values of $\mathrm{R}^{2}$ were analyzed together with those of MSD and $\chi^{2}$, since the latter two were used to determine the accuracy of the model (Kesavan et al., 2019). The MSD values were between 0.0055 and 0.0965 , whereas $\chi^{2}$ data ranged from 0.3567 to $97.8341 \times 10^{-4}$. Under all experimental conditions, regardless of the drying method or layer thickness, the lowest magnitudes of MSD and $\chi^{2}$ were detected in the fitting of the Midilli model, indicating better experimental fit of this model and lower discrepancy between experimental and model-estimated data. Thus, the Midilli model was selected as the most adequate to represent the drying kinetics of Brazil nuts with solar energy, concerning the research conducted under the experimental conditions of this study. These results were positively correlated with the $\mathrm{R}^{2}$ data of the selected model, because the Midilli model also showed the highest absolute values $\left(\mathrm{R}^{2}>0.997\right)$. Reyes et al. (2019) also found adequate fit of the Midilli model for the solar drying of kiwi slices with thicknesses of 4 and $8 \mathrm{~mm}$. Kesavan et al. (2019) found good fit of the Midilli model to the experimental data of solar drying of potato slices, with $\mathrm{R}^{2}$ greater than 0.999 and low values of MSD and $\chi^{2}(0.0057$ and $0.540 \times 10^{-4}$, respectively).

Figure 5 shows the relationship between the experimental moisture ratios and moisture ratios predicted by the Midilli model in the drying of Brazil nut residue with thicknesses of 11.95, 8.06 and $4.11 \mathrm{~mm}$ in a solar dryer and by direct exposure to the sun. It was found that, for any thickness, the values of this relationship were located around the $45^{\circ}$ line, indicating good agreement between the experimental and predicted moisture ratios, being positively correlated with the previously presented MSD and $\chi^{2}$ data of the Midilli model. Santos et al. (2015) also reported good agreement between the moisture ratios obtained experimentally and predicted by the Midilli model, when residual grains of annatto without oil were subjected to solar drying.
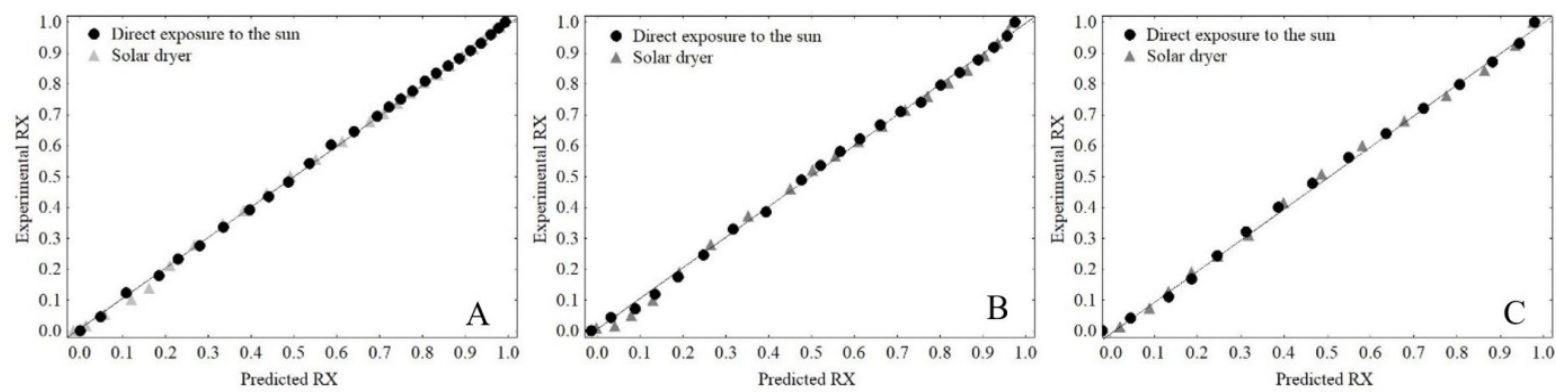

Figure 5. Relationship between the experimental moisture ratios and moisture ratios predicted by the Midilli model in the drying of Brazil nut residue with thicknesses of $11.95 \mathrm{~mm}(\mathrm{~A}), 8.06 \mathrm{~mm}(\mathrm{~B})$ and $4.11 \mathrm{~mm}(\mathrm{C})$ in solar dryer and by direct exposure to the sun. 
The curves of drying kinetics of Brazil nut residue with different thicknesses in solar dryer and by direct exposure to the sun, fitted by the Midilli model, are shown in Figure 6. According to the set of values already presented, expressed by high $\mathrm{R}^{2}$, low MSD and $\chi^{2}$, and agreement between experimental and predicted data, the selection of the Midilli model to describe the phenomenon of heat and mass transfer of Brazil nut residue under the experimental conditions of this study is ratified, since there was no significant dispersion of the data obtained experimentally in relation to the fitted curve. The selection of Midilli model is in agreement with Vidaña et al. (2019), who reported that the use of empirical mathematical models is highly recommended in curves with exponential behavior.
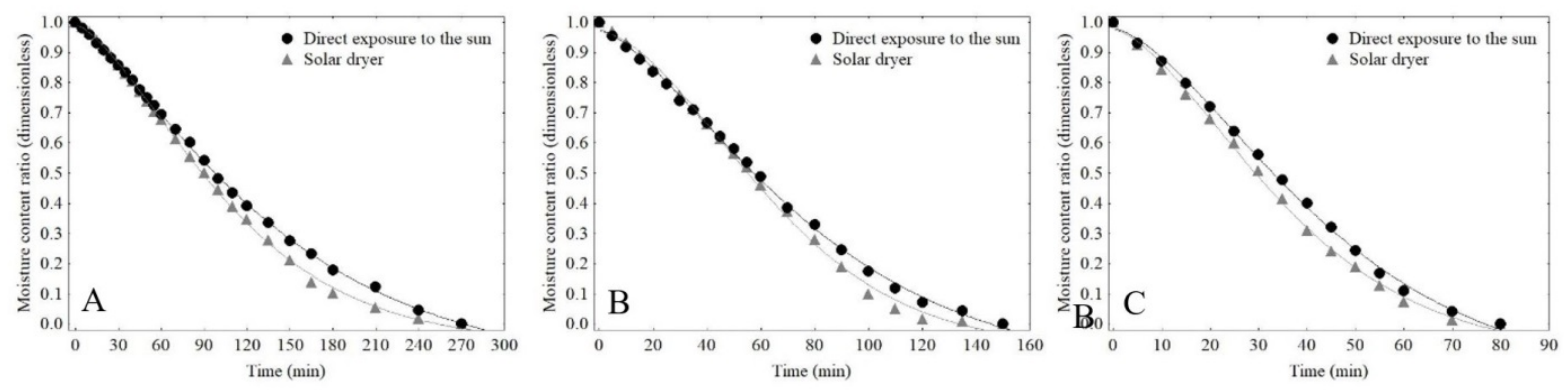

Figure 6. Curves of drying kinetics of Brazil nut residue with thicknesses of $11.95 \mathrm{~mm}$ (A), $8.06 \mathrm{~mm}$ (B) and $4.11 \mathrm{~mm}(\mathrm{C})$ in solar dryer and by direct exposure to the sun fitted by Midilli model.

\subsection{Moisture effective diffusivity}

The effective diffusion coefficients obtained in the drying of Brazil nut residue with different thicknesses in solar dryer and by direct exposure to the sun are presented in Figure 7 . The effective diffusivity in solar dryer was $1.47 \times 10^{-9}$, $1.20 \times 10^{-9}$ and $0.63 \times 10^{-9} \mathrm{~m}^{2} \mathrm{~s}^{-1}$ for the thicknesses of $11.95,8.06$ and $4.11 \mathrm{~mm}$, respectively, whereas the drying by exposure to the sun led to values of $1.29 \times 10^{-9}, 1.11 \times 10^{-9}$ and $0.54 \times 10^{-9} \mathrm{~m}^{2} \mathrm{~s}^{-1}$ for the respective thicknesses of 11.95 , 8.06 and $4.11 \mathrm{~mm}$. In all experiments the values were within the range from $10^{-11}$ to $10^{-9} \mathrm{~m}^{2} \mathrm{~s}^{-1}$ mentioned by Madamba et al. (1996), for the diffusivity of foodstuffs, and close to the values found by Santos et al. (2014b) and Dhalsamant et al. (2017), when drying residual grains of annatto and potato cylinders using solar energy, respectively. For the same layer thickness, it was observed that the samples dehydrated in the solar dryer had the highest effective diffusion coefficients, being positively correlated with the high temperatures of the solar dryer, which increased the vibrational state of the water molecules (Mghazli et al., 2017). This caused the water bonding force with the food matrix to decrease, so less energy was required to remove it from the sample, which resulted in higher effective diffusivity at the highest temperature (Alara et al., 2019). As the layer thickness increased, the effective moisture diffusion coefficients increased by $233.33 \%$ and $238.89 \%$ for samples dehydrated in the solar dryer and by direct exposure to the sun, respectively, when confronting the extremes of diffusivity. This may be related to greater stiffening in samples with smaller thickness, which slows down moisture diffusion, corroborating the results of Fan et al. (2015) who showed similar results. Similar behavior was reported by Abraham-Juárez et al. (2019), who dehydrated prickly pear pulp with thicknesses of 4, 6 and $8 \mathrm{~mm}$ and found an increase of about $350 \%$ in diffusivity as pulp thickness increased.
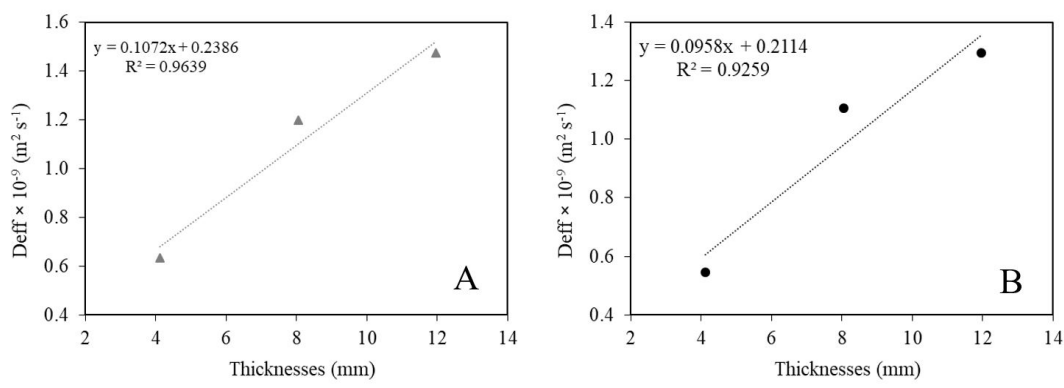

Figure 7. Average values of effective diffusion coefficients ( $\left.D_{\text {eff }}\right)$ obtained in the drying of Brazil nut residue with different thicknesses in solar dryer (A) and by direct exposure to the sun (B). 


\section{Conclusions}

The use of the solar dryer could prove to be feasible under the experimental conditions of this study, and it was possible to obtain temperatures about $80 \%$ higher compared to the temperatures recorded in the external environment. The performance of the device remained high regardless of sample layer thickness, with a tendency to lower discrepancy between the final moisture contents of the drying in solar dryer and the final moisture contents of the drying by exposure to the sun as the thickness decreases. Drying rates were higher in dehydrations performed in the solar dryer compared to the drying by exposure to the sun, with gradual increase in these values as layer thickness decreased. The mathematical model of Midilli was the most adequate for predicting the drying of Brazil nut processing residue under all experimental conditions, with the highest $\mathrm{R}^{2}$ values and the lowest values of DQM and $\chi^{2}$, in addition to good agreement between the experimental and predicted values. Effective moisture diffusion coefficients were higher in samples dehydrated in the solar dryer compared to those dried by exposure to the sun.

\section{References}

Aktaş, M., Şevik, S., Dolgun, E. C., \& Demirci, B. (2019). Drying of grape pomace with a double pass solar collector. Drying Technology, 37(1), 105-117. http://dx.doi.org/10.1080/07373937.2018.1441154

Alara, O. R., Abdurahman, N. H., \& Olalere, O. A. (2019). Mathematical modelling and morphological properties of thin layer oven drying of Vernonia amygdalina leaves. Journal of the Saudi Society of Agricultural Sciences, 18(3), 309-315. http://dx.doi.org/10.1016/j.jssas.2017.09.003

Badaoui, O., Hanini, S., Djebli, A., Haddad, B., \& Benhamou, A. (2019). Experimental and modeling study of tomato pomace waste drying in a new solar greenhouse: Evaluation of new drying models. Renewable Energy, 133(1), 144-155. http://dx.doi.org/10.1016/j.renene.2018.10.020

Brasil. Ministério da Saúde. Agência Nacional de Vigilância Sanitária. (2005, setembro 23). Aprova o Regulamento Técnico para produtos de vegetais, produtos de frutas e cogumelos comestíveis (Resolução de Diretoria Colegiada - RDC $n^{\circ} 272$, de 22 de setembro de 2005). Diário Oficial [da] República Federativa do Brasil, Brasília.

Dhalsamant, K., Tripathy, P. P., \& Shrivastava, S. L. (2017). Moisture transfer modeling during solar drying of potato cylinders considering shrinkage. International Journal of Green Energy, 14(2), 184-195. http://dx.doi.org/10.1080/15435075.2016.1256290

Doymaz, I. (2017). Drying kinetics, rehydration and colour characteristics of convective hot air drying of carrot slices. Heat and Mass Transfer, 53(1), 25-35. http://dx.doi.org/10.1007/s00231-016-1791-8

Fan, K., Chen, C., He, J., \& Yan, F. (2015). Characterization of thin layer hot air drying of sweet potatoes (Ipomoea batatas L.) slices. Journal of Food Processing and Preservation, 39(6), 1361-1371. http://dx.doi.org/10.1111/jfpp.12355

Ferberg, I., Cabral, L. C., Gonçalves, E. B., \& Deliza, R. (2002). Effect of extraction conditions in yield and quality of skinned Brazilian nuts milk. Boletim do Centro de Pesquisa e Processamento de Alimentos, 20(1), 75-88. http://dx.doi.org/10.5380/cep.v20i1.1137

Gomes, S., \& Torres, A. G. (2016). Optimized extraction of polyphenolic antioxidant compounds from Brazil nut (Bertholletia excelsa) cake and evaluation of the polyphenol profile by HPLC. Journal of the Science of Food and Agriculture, 96(8), 28052814. PMid:26353901. http://dx.doi.org/10.1002/jsfa.7448

Guiné, R. P. F., \& Barroca, M. J. (2017). Drying kinetics in solar drying. In O. Prakash \& A. Kumar (Eds.), Solar drying technology: Concept, design, testing, modeling, economics, and environment. Singapore: Springer. http://dx.doi.org/10.1007/978-981-10-3833-4_10

Hamdi, I., Elkhadraoui, A., Kooli, S., Farhat, A., \& Guizani, A. (2019). Drying of red pepper slices in a solar greenhouse dryer and under open sun: Experimental and mathematical investigations. Innovative Food Science \& Emerging Technologies, 52(1), 262-270. http://dx.doi.org/10.1016/j.ifset.2019.01.001

Hempattarasuwan, P., Somsong, P., Duangmal, K., Jaskulski, M., Adamiec, J., \& Srzednicki, G. (2020). Performance evaluation of parabolic greenhousetype solar dryer used for drying of cayenne pepper. Drying Technology, 38(1-2), 48-54. http://dx.doi.org/10.1080/07373937.2019.1609495

Hussein, J. B., Filli, K. B., \& Oke, M. O. (2016). Thin layer modelling of hybrid, solar and open sun drying of tomato slices. Research Journal of Food Science and Nutrition, 1(1), 15-27. http://dx.doi.org/10.31248/RJFSN2016.010 Instituto Adolfo Lutz - IAL. (2008). Normas analíticas, métodos químicos e físicos para análises de alimentos (4. ed.). São Paulo: IAL. Instituto Nacional de Meteorologia - INMET. (2019, July 1). Estação meteorológica de observação de superfície automática. Retrieved in 2020, December 30, from www.inmet.gov.br

Abraham-Juárez, M. R., Olalde-Portugal, V., Cerón-García, A., \& Sosa-Morales, M. E. (2019). Hot air drying kinetics of thin layers of prickly pear fruit paste. Sains Malaysiana, 48(2), 361-366. http://dx.doi.org/10.17576/jsm-2019-4802-13

Kesavan, S., Arjunan, T. V., \& Vijayan, S. (2019). Thermodynamic analysis of a triple-pass solar dryer for drying potato slices. Journal of Thermal Analysis and Calorimetry, 136(1), 159-171. http://dx.doi.org/10.1007/s10973-018-7747-0 
Kluczkovski, A., Lima, N., \& Oliveira, M. K. (2017). Brazil nut powdered milk properties. Journal of Food Processing and Preservation, 41(5), 1-6. http://dx.doi.org/10.1111/jfpp.13147

Lakshmi, D. V. N., Muthukumar, P., Ekka, J. P., Nayak, P. K., \& Layek, A. (2019). Performance comparison of mixed mode and indirect modep arallel flow forced convection solar driers for drying Curcuma zedoaria. Journal of Food Process Engineering, 42(4), 1-12. http://dx.doi.org/10.1111/jfpe.13045

Lingayat, A., Chandramohan, V. P., \& Raju, V. R. K. (2017). Design, development and performance of indirect type solar dryer for banana drying. Energy Procedia, 10(1), 409-416. http://dx.doi.org/10.1016/j.egypro.2017.03.041

Lingayat, A., Chandramohan, V. P., \& Raju, V. R. K. (2020). Energy and exergy analysis on drying of banana using indirect type natural convection solar dryer. Heat Transfer Engineering, 41(6-7), 551-561. http://dx.doi.org/10.1080/01457632.2018.1546804

Madamba, P. S., Driscoll, R. H., \& Buckle, K. A. (1996). The thin layer drying characteristic of garlic slices. Journal of Food Engineering, 29(1), 75-97. http://dx.doi.org/10.1016/0260-8774(95)00062-3

Mghazli, S., Ouhammou, M., Hidar, N., Lahnine, L., Idlimam, A., \& Mahrouz, M. (2017). Drying characteristics and kinetics solar drying of moroccan rosemary leaves. Renewable Energy, 109(1), 303-310. http://dx.doi.org/10.1016/j.renene.2017.02.022

Murali, S., Sathish Kumar, K., Alfiya, P. V., Delfiya, D. S. A., \& Samuel, M. P. (2019). Drying kinetics and quality characteristics of indian mackerel (Rastrelliger kanagurta) in solar-electrical hybrid dryer. Journal of Aquatic Food Product Technology, 28(5), 541-554. http://dx.doi.org/10.1080/10498850.2019.1604597

Patil, R. C., \& Gawande, R. R. (2018). Drying characteristics of amla candy in solar tunnel greenhouse dryer. Journal of Food Process Engineering, 41(6), 1-11. http://dx.doi.org/10.1111/jppe.12824

Queiroz, A. J. M., Dantas, H. J., Figueirêdo, R. M. F., \& Melo, K. S. (2011). Solar drying of jack fruit almonds. Engenharia Agrícola, 31(6), 1150-1161. http://dx.doi.org/10.1590/S0100-69162011000600012

Reyes, A., Vásquez, J., Pailahueque, N., \& Mahn, A. (2019). Effect of drying using solar energy and phase change material on kiwifruit properties. Drying Technology, 37(2), 232-244. http://dx.doi.org/10.1080/07373937.2018.1450268

Santos, D. C., Queiroz, A. J. M., Figueirêdo, R. M. F., \& Oliveira, E. N. A. (2013). Mathematical modeling for the annatto (Bixa orellana L.) seed drying process. Chilean Journal of Agricultural Research, 73(3), 320-326. http://dx.doi.org/10.4067/S071858392013000300017

Santos, D. C., Queiroz, A. J. M., Figueirêdo, R. M. F., \& Oliveira, E. N. A. (2014a). Solar drying of annatto grains and waste grains flour of annatto. Bioscience Journal, 30(2), 436-446.

Santos, D. C., Queiroz, A. J. M., Figueirêdo, R. M. F., \& Oliveira, E. N. A. (2014b). Drying grain residual annatto by sun combined with drying in dryer with heat accumulator. Semina: Ciências Agrárias, 35(1), 277-290. http://dx.doi.org/10.5433/16790359.2014v35n1p277

Santos, D. C., Queiroz, A. J. M., Figueirêdo, R. M. F., \& Oliveira, E. N. A. (2015). Sun drying of residual annatto seed powder. Acta Scientiarum. Technology, 37(1), 161-166. http://dx.doi.org/10.4025/actascitechnol.v37i1.20582

Santos, D. C., Leite, D. D. F., Lisbôa, J. F., Ferreira, J. P. L., Santos, F. S., Lima, T. L. B., Figueiredo, R. M. F., \& Costa, T. N. (2019). Modelling and thermodynamic properties of the drying of acuri slices. Brazilian Journal of Food Technology, 22(1), 1-12. http://dx.doi.org/10.1590/S1981-67232012000100001

Seerangurayar, T., Al-Ismaili, A. M., Jeewantha, L. H. J., \& Al-Nabhani, A. (2019). Experimental investigation of shrinkage and microstructural properties of date fruits at three solar drying methods. Solar Energy, 180(1), 445-455. http://dx.doi.org/10.1016/j.solener.2019.01.047

Singh, P., Vyas, S., \& Yadav, A. (2020). Experimental comparison of open sun drying and solar drying based on evacuated tube collector. International Journal of Sustainable Energy, 38(4), 348-367. http://dx.doi.org/10.1080/14786451.2018.1505726

Tagnamas, Z., Bahammou, Y., Kouhila, M., Hilali, S., Idlimam, A., \& Lamharrar, A. (2019). Conservation of Moroccan truffle (Terfezia boudieri) using solar drying method. Renewable Energy, 146(1), 16-24. http://dx.doi.org/10.1016/j.renene.2019.06.107 Vidaña, E. C. L., Figueroa, I. P., Marcos, E. G. A., Ocaña, A. N., Vázquez, L. H., \& Urbina, J. A. S. (2019). Solar drying kinetics and bioactive compounds of blackberry (Rubus fruticosus). Journal of Food Process Engineering, 42(4), 1-9. http://dx.doi.org/10.1111/jfpe.13018

Funding: Instituto Federal do Acre. 